\title{
THE EFFECT OF GUIDED DISCOVERY INSTRUCTIONAL STRATEGY ON GRADE NINE LEARNERS' PERFORMANCE IN CHEMICAL REACTIONS IN MANKWENG CIRCUIT, SOUTH AFRICA
}

\author{
Israel Kibirige iD, Rebecca Mampageti Maake iD \\ University of Limpopo (South Africa) \\ Israel.Kibirige@ul.ac.za,remaake@gmail.com
}

Received April 2021

Accepted June 2021

\section{Abstract}

Teaching strategies play a vital role in improving learners' performance. This study investigated the effect of Guided Discovery Instructional Strategy (GDIS) on Grade nine learners' performance in chemical reactions and determined the effect of GDIS on gender. A quasi-experimental design with a sample comprising 75 grade nine learners was purposively selected from two schools in Mankweng Circuit based on Grade 12 performance. Learners were randomly assigned to the Experimental Group (EG) $(N=40)$ and Control Group (CG) $(\mathrm{N}=35)$ taught for two weeks using GDIS for EG and Talk and Chalk Method (TCM) for CG. The results show that there were statistically significant differences in post-test of EG $(\mathrm{M}=67.60, \mathrm{SD}=18.70)$ and $\mathrm{CG}(\mathrm{M}=37.86, \mathrm{SD}=18.01)(\mathrm{T}$-test: $\mathrm{t}(73)=6.99 ; \mathrm{p}<0.05)$ and a Cohen $\mathrm{d}=$ 0.6. EG taught using GDIS outperformed CG taught using TCM (ANCOVA: $\mathrm{F}=15.93, \mathrm{p}<0.05$ ). GDIS favoured both males and females (Mann Whitney U-test: $\mathrm{U}=153.00, \mathrm{p}=0.22$, suggesting that GDIS improved all learners' performance in chemistry, but not TCM. The findings provide teachers and stakeholders with empirical evidence on a strategy that improved learners' performance. Also, GDIS did not discriminate against gender, suggesting that the strategy encourages girls to study science, contributing to narrowing the existing gender gap between males and females in Science, Technology, Engineering and Mathematics (STEM) subjects.

Keywords - Guided discovery instructional strategy, Talk and chalk method, Learners' performance, Conceptual understanding.

\section{To cite this article:}

Kibirige, I., \& Maake, R.M. (2021). The effect of guided discovery instructional strategy on grade nine learners' performance in chemical reactions in Mankweng Circuit, South Africa. Journal of Technology and Science Education, 11(2), 569-580. https://doi.org/10.3926/jotse.1295

\section{Introduction}

Teaching strategies play a vital role in learners' performance. Poor performance in science is a national concern (Petrus, 2018; Van der Berg, van Wyk, Burger, Kotzé, Piek \& Rich, 2017). Grade 12 Physical Sciences diagnostic reports show that learners performed poorly on the rate of reactions with a mean score of 23.7\% (Department of Basic Education, 2012). There are several other learners' cognitive challenges concerning chemical reactions. For example, learners could not write down the name of 
$\mathrm{CO}_{2}(\mathrm{~g})$, and they did not know that (g) means gas (Department of Basic Education, 2012). Chemical reactions is one of the difficult concepts taught in high school (Ayyildiz \& Tarhan, 2012). In South Africa, the concept of chemical reactions is introduced in Grade nine according to the Curriculum Assessment Policy Statements (CAPS). Learners start with the basics in the lower primary school and expand on it in the Senior Phase. The difficulty of teaching chemical reactions is compounded by the lack of adequate resources in some schools. In addition, teachers have conceptual challenges to teach chemical reactions (Marina, Vladimir \& Bojan, 2012). Learners' poor performance in science is exacerbated by large classes, lack of resources, lack of professionally qualified teachers, inadequate mastery of subject content by some teachers, inappropriate teaching strategies, conceptual challenges (misconceptions), lack of motivation and interest, non-completion of the syllabus, and lack of meaningful assessment (Ajaja, 2009; Mji \& Makgato, 2006). There is a need for teachers to use an instructional strategy that improves learners' performance.

Guided Discovery Instructional Strategy is generally defined as instruction in which learners construct essential information for themselves with minimum guidance from the teacher (Shieh \& Yu, 2016). Learners play an active role in groups starting from the problem statement, data collection and processing, data verification to concluding their findings (Yerizon, Putra \& Subhan, 2018). Active learning requires a hands-on approach and requires learners to engage their minds in the process of inquiry learning (Khan, Egbue, Palkie \& Madden, 2017). One of the theories neglected in the teaching of science is the constructivism theory. Constructivists believe in designing activities where learners are actively learning to gain knowledge rather than transmitting knowledge. Constructivist theorists believe that teachers should deal with learners having high abilities or high motivation for science and be concerned with different levels of learners' cognitive and affective dimensions. Here, the teacher's guidance is crucial for the learning process. Four Guided Discovery Instructional Strategy tenets include: 1) task setting (Akanbi \& Kolawole, 2014), which involves the teacher showing an open-ended question and telling the first part of a story and leaving the next part open to interpretation; 2) collaboration (DfES, 2002), where learners communicate; 3 ) monitoring how well the learners are progressing and scaffolding them whenever they face challenges (Mazzoni \& Gaffuri, 2009); and 4) consolidating concepts, which requires learners to think aloud, do self-question, examine steps they took to conclude, and to derive meanings of what is learnt (Zohar \& Barzilai, 2013).

A few studies show that some learners resist active learning (Seidel \& Tanner 2013; Scheyvens, Griffin, Jocoy, Liu \& Bradford, 2008; Shekhar, Demonbrun, Borrego, Finelli, Prince, Henderson et al., 2015) and that serious engagement could hamper learners' working memory (Kirschner, Sweller \& Clark, 2006; Michael, 2006). This school of thought has not been supported by research, and it falls away (Talheimer, 2010) in favour of learners' engagement to learn. Several studies support learners' engagement in active learning strategies like GDIS to improve performance (Michael, 2006; Vosniadou, Ioannides, Dimitrakopoulou \& Papademetriou, 2001; Owens, Sadler, Barlow \& Smith-Walters, 2020).

In Kenya, Amukowa and Karue (2013) studied factors affecting Kenya's Certificate of Secondary Education performance in day secondary schools in Embu District of Eastern Province. The study findings showed unfavourable home environments and family backgrounds as factors responsible for poor performance. In addition, lack of reading materials, chores at home, poor lighting, bad company, lack of proper accommodation, chronic absenteeism emanating from lack of school fees, admission of weak learners at Form one entry (first level of high school), inadequate instructional materials and physical facilities accounted for poor learners' performance in Kenya.

Learners' poor performance in science has been a recurrent challenge in Limpopo Province, South Africa (van der Berg et al., 2017; Petrus, 2018). Poor performance denies learners' entry into university science degree programmes. The final results of Grade 12 learners from two high schools (A and B) for 20112019 are presented (Table 1).

Mji and Makgato (2006) investigated factors associated with high school learners' poor performance and found that teaching strategies, content knowledge, motivation, laboratory use, and non-completion of the 
syllabus in a year were responsible for the poor results. In South Africa, poor results were attributed to parental involvement and Language of Learning and Teaching (LoLT). For example, in KwaZulu-Natal public schools, Physical Sciences Grade 12 poor performance was attributed to lack of resources, challenges with LoLT, learners doing Mathematical Literacy instead of Mathematics, the socio-economic status of learners, parental involvement, large classes, and the curriculum (Dhurumraj, 2013). Thus, no single factor accounts for poor performance in Physical Sciences. The findings from various studies (Amukowa \& Karue, 2013; Dhurumraj, 2013; Mji \& Makgato, 2006) indicate that factors contributing to poor learner performance in sciences are complex.

\begin{tabular}{|l|r|r|}
\hline Year & \% pass for high school A & \% pass for high school B \\
\hline 2011 & 45.9 & 33.2 \\
\hline 2012 & 57.3 & 39.6 \\
\hline 2013 & 32.1 & 40.4 \\
\hline 2014 & 60.7 & 32.1 \\
\hline 2015 & 34.0 & 23.0 \\
\hline 2016 & 42.0 & 32.0 \\
\hline 2017 & 37.0 & 40.0 \\
\hline 2018 & 47.1 & 54.9 \\
\hline 2019 & 63.0 & 44.8 \\
\hline
\end{tabular}

Table 1. Percentage passes in Physical Sciences in two schools in Mankweng Circuit from 2011-2019

This study used social constructivists' theory (Vygotsky, 1978) as a lens to understand the effect of the teaching strategy. The social constructivists' theory affirms that knowledge is created when learners interact with the environment. Learners build new knowledge based on their prior knowledge and engage in active learning instead of passive learning. Active learning is a two-way process with both the teacher and the learner learning to minimise learners' knowledge gaps. In general, constructivism emphasises the creation of the meaning of the world through a series of individual constructs to understand science. The constructivist teaching and learning models involve factors like the active learning process, minds-on learning, developing cognitive processes, and questioning the validity of the situation. In South Africa, CAPS stipulates that science teachers should use constructivist teaching strategies to engage learners in problem-solving activities, independent learning, critical thinking and understanding, and creative learning, rather than rote learning and memorisation. Learners should have a solid foundation in science before entering the University system.

Teachers need to have Pedagogy and Content Knowledge (PCK) to inculcate such a solid science foundation in learners. Unfortunately, teachers have challenges with content and teaching strategies (Udo, 2010). Teachers use TCM where they provide information, explain concepts and procedures to learners (Clark, Kirschner \& Sweller, 2006). It is a teaching strategy in which the teacher presents knowledge and skills and explicitly provides notes for learners to read and memorise for the tests or examinations. Learners memorise what the teacher provided rather than discover concepts (Mayer, 2004). A study by Udo and Udo (2007) indicated that TCM is ineffective in providing a firm foundation to improve learners' performance.

During TCM, teachers specify learning objectives and arrange information to memorise (Moreno, 2004). There is very little emphasis on conceptual and cognitive challenges. Consequently, learners taught using TCM do not master concepts effectively; instead, they memorise and later forget what they were taught (Mayer, 2004). Additionally, TCM results in what is referred to as the "drill and kill" method (Baek, Yoo, Lee, Jung \& Baek, 2017). It is imperative to find teaching strategies that improve learners' understanding of science concepts. One strategy is Guided discovery, a two-way process where learners are active in class guided by their teachers (Loibl \& Rummel, 2014) to solve the problem and minimise learners' knowledge gaps (Martin, 2015). Few studies have dealt with chemical reactions in chemistry, and this is a knowledge 
gap which this study fills. Therefore, this study aimed to investigate the effect of GDIS on Grade nine learners' performance in chemical reactions and to establish the effect of GDIS on gender. The following null hypotheses guided the study: 1) There are no statistically significant differences in performance between learners taught chemical reactions using GDIS and learners taught using TCM. 2) There are no statistically significant differences between the performance of males and females taught chemical reactions using GDIS.

\section{Methodology}

\subsection{Research Design}

The study adopted a quasi-experimental pre-and post-test non-randomised group design (Cohen, Manion $\&$ Morrison, 2007). The quasi-experimental design provides reasonable control over threats to the internal validity (McMillan \& Schumacher, 2010). This design was suitable as it allowed for a comparison of the Experimental Group (EG) and Control Group (CG).

\subsection{Participants of the Study}

Participants comprised 75 Grade nine learners belonging to General Education and Training (GET) (Grades seven to nine) from two intact classes from two different schools. The learners' age ranged from 17 to 19 and learners had similar academic backgrounds. The selected classes were randomly assigned to the $E G(N=40)$ and $C G(N=35)$.

\subsection{Implementation}

The two groups were taught chemical reactions for two weeks by the same teacher following the four tenets of Guided Discovery: task setting, collaborating, monitoring and consolidating. The topics included: 1) Substances react with each other to form products with different chemical properties; 2) Investigating the chemical reaction that takes place when a whole egg is placed in white vinegar; 3) Investigating what happens when you blow air with a drinking straw into clear limewater in a beaker, and 4) Using indigenous knowledge to understand fermentation in brewing alcohol. Before the teaching began, the second author acclimatised EG learners on the tenets of GDIS and how to arrive at the whole picture of the activities. EG was taught using GDIS, where they wrote down observations, predictions, and explanations for each activity in class, and ended up with a big picture of the content. The teacher in EG engaged learners in five elements of STEM: 1) Problem-Based-Learning - like what happens when an egg is immersed in vinegar for a night (for learners to reflect on their learning), 2) Engaged learners in real-world contexts: like how to brew traditional alcohol, 3) Career, Technology, and Life Skills - like teamwork and collaboration among students, and learner autonomy during report writing, 4) Rigorous Learning - learners made connections between the content (vinegar use and traditional alcohol brewing) and the environment, 5) School Community and Belonging where learners were inducted into GDIS and school learning ethos when working in teams. One activity was about brewing traditional beer 'umqombothi' using four steps:

1. Mix (1 $\mathrm{kg}$ sorghum malt, $1 \mathrm{~kg}$ mealie meal, and $1 \mathrm{~kg}$ wheat malt) together in a 10 or 20 litre bucket. Place a cover without tight sealing. Let the content ferment overnight close to a fireplace. Stir and fill $70-80 \%$ of the bucket with warm water and heat to boiling point.

2. Add fermented mixture to the boiling water to form a slurry.

3. Cool the slurry for one day, then add enough wheat malt $(1-3 \mathrm{~kg})$ and stir.

4. Filter the fermented mixture using a clean cloth or a sieve to remove suspended solids. The solution (filtrate) is the beer ready for consumption or storage for later use.

Learners established how to follow steps and control for contaminations and toxic substances. Learners linked these control steps to industrial beer brewing processes. For example, the role of Wickerhamomyces anomalus yeast added to the mixture was to minimise toxicity in industrial brewing. In traditional brewing, 
they added 1-3 kg of wheat malt. Also, they learnt Umqombothi contained an extortionate amount of iron. Learners wrote the balanced chemical equation for brewing 'Umqombothi' and reflected on the process. In the CG, the teacher elaborated the processes and wrote notes on the chalkboard for learners to read and memorise for examination with little engagement with the learners' conceptual understanding. For example, the teacher explained to learners the processes such as the brewing of traditional beer, 'umqombothi'. The teacher wrote the equations on the chalkboard for the learners to copy and memorise. Both the EG and CG were subjected to a Performance Test (PT) to determine the level of conceptual understanding regarding chemical reactions before interventions. After the intervention, the researchers administered the PT as a post-test to both groups during school testing. The PT questions in the post-test were the same as the pre-test, but the numbers were re-arranged to minimise recognition. The dependent variable measured was the test scores of the two groups. The independent variable manipulated was the teaching strategy, which differed in EG and CG. The extraneous variables were controlled using the following precautions: 1) learners in the two groups were taught similar themes on chemical reactions, 2) the second author taught the two groups to minimise personality differences, 3) learners were taught following the normal school timetable to avoid disrupting school schedules, and 4) the time for teaching the content was the same in EG and CG. 5) the two schools were far apart to avoid contamination by CG sharing ideas with EG.

\subsection{Research Instruments}

The second author designed the Performance Test (PT) (Table 2) to determine the learners' performances before and after teaching. Two experts validated the questions, which were piloted to 10 learners who were not part of the study, and a Cronbach Alpha of 0.75 was achieved, suggesting the questions were suitable for the study.

\begin{tabular}{|c|c|}
\hline (Questions) & \multirow[b]{2}{*}{ (Total Marks 100) } \\
\hline Section A (48 marks) & \\
\hline $\begin{aligned} \text { Balance the equations and write word equations for questions } 1-6 \text { below: } \\
\begin{aligned} \text { 1. } & \mathrm{H}_{2}+\mathrm{O}_{2} \rightarrow \mathrm{H}_{2} \mathrm{O} \\
\text { 2. } & \mathrm{Ca}+\mathrm{O}_{2} \rightarrow \mathrm{CaO} \\
\text { 3. } & \mathrm{Mg}+\mathrm{O}_{2} \rightarrow \mathrm{MgO} \\
\text { 4. } & \mathrm{H}_{2}+\mathrm{I}_{2} \rightarrow \mathrm{HI} \\
\text { 5. } & \mathrm{Na}+\mathrm{Cl}_{2} \rightarrow \mathrm{NaCl} \\
\text { 6. } & \mathrm{Ca}+\mathrm{CO}_{3} \rightarrow \mathrm{CaCO}_{3}\end{aligned}\end{aligned}$ & $\begin{array}{l}{[8 \text { marks }]} \\
{[8 \text { marks }]} \\
{[8 \text { marks }]} \\
{[8 \text { marks }]} \\
{[8 \text { marks }]} \\
{[8 \text { marks }]}\end{array}$ \\
\hline \multicolumn{2}{|l|}{ Section B (52 marks) } \\
\hline $\begin{array}{l}\text { Read the following instructions questions } 7-10 \text { and answer as instructed per question: } \\
\text { 7. Explain using a chemical equation what happens to a piece of glucose that is eaten } \\
\text { by human beings. }\end{array}$ & [10 marks] \\
\hline $\begin{array}{l}\text { 8. Explain what happens when you submerge an egg in vinegar overnight and write } \\
\text { the chemical equation involved in the process. } \\
\text { 9. Write the chemical equation of fermentation of glucose, and name the main } \\
\text { product formed. }\end{array}$ & $\begin{array}{l}\text { [12 marks] } \\
{[10 \text { marks }]}\end{array}$ \\
\hline $\begin{array}{l}\text { 10. Write the chemical reactions that take place when one blows air through a drinking } \\
\text { straw into limewater in a beaker: } \\
\begin{array}{l}\text { a) For a short time. } \\
\text { b) For a long time. }\end{array}\end{array}$ & [20 marks] \\
\hline
\end{tabular}

Table 2. Performance Test for Grade nine Physical Sciences

\subsection{Data Analysis}

Data were analysed using descriptive statistics: Means and Standard Deviations, medians, and inferential statistics: T-test, and Analysis of Covariance (ANCOVA), where the pre-test was used as a covariate, and a Mann Whitney U-test. All data were analysed using the Statistical Package for Social Sciences (SPSS) version 27. 


\section{Results and Discussion}

The results show that EG taught using Guided Discovery Instructional Strategy (GDIS) performed better than the CG taught using Talk and Chalk Method (TCM). A T-test between EG and CG before the study showed that there were no statistically significant differences in the pre-test results of the $E G(M=22.25$, $\mathrm{SD}=6.16)$ and $\mathrm{CG}(\mathrm{M}=22.43, \mathrm{SD}=6.10)$ with an effect size $(\mathrm{d}=0.03)$ (Table 3$)$, suggesting that the two groups had a similar conceptual understanding of chemical reactions at the beginning of the study. An independent sample T-test shows that there were statistically significant differences between post-test for $\mathrm{EG}(\mathrm{M}=67.60, \mathrm{SD}=18.70)$ and $\mathrm{CG}(\mathrm{M}=37.86, \mathrm{SD}=18.01)$, (T-test: $\mathrm{t}(73)=6.99 ; \mathrm{p}<0.05)$ with an effect size (Cohen $d=0.6)$.

T-test analysis was used to compare the pre-test and post-test results of the EG and CG (Table 3).

\begin{tabular}{|l|l|r|r|r|r|r|r|}
\hline \multicolumn{1}{|c|}{ Test } & \multicolumn{1}{c|}{ Group } & \multicolumn{1}{c|}{ n } & \multicolumn{1}{c|}{ M } & \multicolumn{1}{c|}{ SD } & \multicolumn{1}{c|}{ t } & \multicolumn{1}{c|}{ p } & \multicolumn{1}{c|}{ d } \\
\hline Pre-test & Experimental & 40 & 22.25 & 6.16 & 0.13 & 0.90 & 0.03 \\
\hline & Control & 35 & 22.43 & 6.10 & & & \\
\hline Post- test & Experimental & 40 & 67.60 & 18.70 & 6.99 & 0.00 & 0.60 \\
\hline & Control & 35 & 37.86 & 18.01 & & & \\
\hline
\end{tabular}

Table 3. T-test results of the pre-tests and post-tests of both the EG and CG (*significant at p $<0.05)$

Table 3 shows no statistically significant differences between pre-test of $E G(M=22.25, \mathrm{SD}=6.16)$ and $\mathrm{CG}(\mathrm{M}=22.43, \mathrm{SD}=6.10)(\mathrm{T}$-test: $\mathrm{t}(73)=0.13 ; p>0.05)$ with Cohen $d=0.03$. The lack of significant differences in scores between the EG and CG in the pre-test suggests that learners had a similar conceptual understanding before the teaching and intervention. There were statistically significant differences in post-test of $\mathrm{EG}(\mathrm{M}=67.60, \mathrm{SD}=18.70)$ and $\mathrm{CG}(\mathrm{M}=37.86, \mathrm{SD}=18.01)$ (T-test: $\mathrm{t}(73)=6.99 ; p<0.05)$ and a Cohen $d=0.60$. It suggests that EG had higher gains (Cohen $d=0.6)$ than the CG (Cohen $d=0.03$ ). Thus, this study accepts the hypothesis that there were significant differences in performance between learners taught chemical reactions using GDIS and learners taught using TCM. The post-test mean score for the EG was higher than for the CG. It shows that learners who were taught using GDIS understood chemical reactions better than those taught using TCM. The higher performance in EG suggests that learners improved in conceptual understanding of chemical reactions because they were engaged in active learning. This observation agrees with Kibirige and Tsamago (2019), who found better understanding when learners were actively engaged in simulations using computers in South Africa. Also, EG learners taught using GDIS were likely motivated more than CG learners taught using TCM. This observation agrees with Peterson (1979), who contends that the GDIS motivates learners more than the traditional teaching approach. It is, therefore, no wonder the EG achieved higher performance than the learners in CG. The findings of this study agree with those of Udo (2010) and Garuma and Tesfaye (2012), who found that GDIS improved learners' performance better than the traditional instructional methods. It is because learners learn better by doing than by being passive (Magana, Vieira \& Boutin, 2018; Roberts, 2019). Learners taught using TCM scored low because the teacher transmitted knowledge to them, and little attention was paid to ascertain learners' conceptual understanding (Mayer, 2004).

ANCOVA was used to establish the effect of GDIS on learners' performance using the pre-tests as a covariate (Table 4).

Table 4 shows a significant effect between EG and CG post-tests with pretests as a covariate $\mathrm{F}(2.72)=15.93, \mathrm{p}=0.00$. Therefore, the null hypothesis is rejected, which states that no statistically significant differences in performance between learners taught chemical reactions using GDIS and learners taught using TCM and accept the alternate hypothesis that there were statistically significant differences between learners taught using GDIS and learners taught using TCM. The effect size for treatment (GDIS) is large, with a partial eta squared $(\eta 2=0.41)$. It shows that GDIS improved learners' understanding and performance in chemical reactions. Although Grade nine learners in both the CG and 
EG were at the same level of understanding at the beginning of the intervention, after intervention using GDIS, the EG had higher performance than their counterparts in the CG. The results suggest that GDIS is a good teaching strategy for conceptual understanding. Learners in EG engaged in identifying different reactions, predicting and writing explanations. These findings agree with Shieh and Yu (2016), who found that Guided Discovery improved learners' science and mathematics conceptual understanding. Similarly, guided discovery improves performance in other subjects like mathematics (Yerizon et al., 2018).

\begin{tabular}{|l|r|r|r|r|r|r|}
\hline \multicolumn{1}{c|}{ Source } & $\begin{array}{c}\text { Type III Sum } \\
\text { of Squares }\end{array}$ & df & Mean Square & \multicolumn{1}{c|}{ F } & \multicolumn{1}{c|}{ Sig. } & \multicolumn{1}{c|}{$\begin{array}{c}\text { Partial Eta } \\
\text { Squared }\end{array}$} \\
\hline Corrected Model & $17550.50^{\mathrm{a}}$ & 3 & 8775.25 & 26.73 & 0.00 & .43 \\
\hline Intercept & 133927.85 & 1 & 133927.85 & 407.96 & 0.00 & .85 \\
\hline Pre-test EG & 1037.26 & 1 & 1037.26 & 3.16 & 0.08 & .04 \\
\hline Group1 \& & 16520.42 & 2 & 16520.42 & 15.93 & 0.00 & .41 \\
\hline Error & 23636.62 & 72 & 328.29 & & & \\
\hline Total & 257625.00 & 75 & & & & \\
\hline Corrected Total & 41187.12 & 74 & & & & \\
\hline
\end{tabular}

a. $\mathrm{R}$ Squared $=.43$ (Adjusted R Squared $=0.41$ )

Table 4. ANCOVA summary of post-tests EG and CG with pre-tests as the covariate

The EG pre-test performances of males and females were tested using a Mann Whitney U-test (Table 5).

\begin{tabular}{|l|r|r|r|}
\hline \multicolumn{3}{|c|}{ Test Statistics $^{\text {a }}$} \\
\hline & Pre-test Males \& Females & Male & Female \\
\hline Mann-Whitney U & 153.50 & & \\
\hline Wilcoxon W & 406.50 & & \\
\hline Z & -1.21 & & \\
\hline Asymp. Sig. (2-tailed) & 0.23 & & \\
\hline Exact Sig. [2*(1-tailed Sig.)] & $0.23^{\mathrm{b}}$ & & \\
\hline a. Grouping Variable: Group & & & \\
\hline b. Not corrected for ties. & & & \\
\hline Median & & 22.50 & 19.50 \\
\hline
\end{tabular}

Table 5. A Mann Whitney U-test on the males and females' pre-test performance in EG.

In Table 5, a Mann-Whitney test shows males' performance in pre-test was slightly higher $(\mathrm{Mdn}=22.50)$ than females $(\mathrm{Mdn}=19.50), \mathrm{U}=153.50, \mathrm{p}=0.23$. However, the performances of males and females are not significantly different (Mann Whitney U-test, $\mathrm{p}=0.23$ ).

The EG post-test performances of males and females were tested using a Mann Whitney U-test (Table 6).

\begin{tabular}{|l|r|r|r|}
\hline \multicolumn{3}{|c|}{ Test Statistics $^{\mathbf{a}}$} \\
\hline & Male and Female & \multicolumn{1}{|c|}{ Male } & Female \\
\hline Mann-Whitney U & 153.00 & & \\
\hline Wilcoxon W & 406.000 & & \\
\hline Z & -1.23 & & \\
\hline Asymp. Sig. (2-tailed) & 0.22 & & \\
\hline Exact Sig. [2*(1-tailed Sig.)] & $0.23^{\text {b }}$ & & \\
\hline a. Grouping Variable: Group & & & \\
\hline b. Not corrected for ties. & & \\
\hline Median & & 68.50 & 65.50 \\
\hline
\end{tabular}

Table 6. A Mann Whitney U-test on the males and females' posttest performance in EG 
In Table 6 a Mann-Whitney test shows males' performance in post-test was slightly higher $(\mathrm{Mdn}=68.50)$ than females' $(\mathrm{Mdn}=65.50), \mathrm{U}=153.00, \mathrm{p}=0.22$. The performance of males and females is not significantly different (Mann Whitney U-test, $\mathrm{p}=0.22)$. Judging from the pre-test $(p<0.05)$ males and females in the EG had a similar understanding of chemical reactions (Table 5). After the intervention, both genders improved in their performance, and there were no significant differences in performance between the males and females. Thus, these results suggest that both genders performed equally well when taught chemical reactions using GDIS. It may be because good teaching strategies are not gender-biased (Bussey \& Bandura, 1999). Thus, gender did not affect learners' performance in chemical reactions. It implies that the performance among learners taught with GDIS was a result of the instruction method. Thus, the finding of this study has far-reaching implications in science education because it bridges the gap between males' and females' performance in science subjects. A few studies show that physics and chemistry are masculine subjects (Reinking \& Martin, 2018; Makarova, Aeschlimann \& Herzog, 2019). Reinking and Martin (2018), attribute this gender bias to three theories: 1) gender socialisations where boys and girls are raised to socialise differently based on their gender; 2) peer pressure where each gender is pressured to conform with the gender norms; 3) engagement in STEM fields. For instance, the third theory has to do with classroom learning engagement, where activities favour one gender over the other. It is crucial for teachers to understand adolescents above 15 years, when interests fluctuate dramatically and lean towards future gender roles in the labour market (OECD, 2006). Also, it is alleged that human-centred fields are feminine, while technical and mathematics intensive fields are masculine (Charles \& Bradley, 2009). In our study, GDIS favoured both genders. It implies that both genders improved their skills in five STEM elements: Problem Based Learning; Career, Technology, and Life Skills; Rigorous Learning; and School Community and belonging. For instance, during GDIS, EG noted avoiding toxicity during brewing and established the high iron content in 'Umqomboth', while CG taught using TCM did not have the same experience. The observation regarding iron content in traditional beer concurs with Choma, Alberts and Urdal (2007), who found that Umqombothi drinkers did not suffer from iron deficiency (anaemia). EG taught using GDIS, where they recorded observations, predictions, and explanations for each activity in class ended up with a big picture of the content. It is no wonder males and females in EG must have enjoyed learning science using GDIS. It is reasonable to conclude that using GDIS to teach science can narrow the existing gender gap in STEM.

\section{Limitations of the Study}

The research was conducted among Grade nine Natural Sciences learners in one Circuit of Limpopo Province, and thus the findings cannot be generalisable to the entire province and the country. The non-random selection and assignment of participants to the EG and CG is another limitation. The sample could not be distributed equally between EG and CG because schools were natural settings that the researchers did not disrupt, resulting in an uneven distribution of males and females in the EG and CG. The intervention period was short because the researcher was allowed to use only the time required by curriculum policy documents to teach chemical reactions.

\section{Conclusions}

This study established that Guided Discovery Instructional Strategy (GDIS) improved learners' conceptual understanding regarding chemical reactions in Mankweng Circuit, South Africa. The EG had higher gains than the CG taught using Talk-and-Chalk Method (TCM), suggesting that GDIS improved learners' science understanding. Males and females in EG taught using GDIS performed equally well, signifying that the strategy favoured both genders. This study has long-term implications in the teaching strategies in the General Education and Training (GET) Grades seven to nine and Further Education and Training (FET) Grades 10 to 12. Using GDIS in science teaching can narrow the ever-existing gender gap in STEM and improve learners' performance at all levels of education. Future research should investigate the effects of GDIS on other science topics using a qualitative approach to capture the human social issues often missed in quantitative studies. 


\section{Acknowledgement}

The authors acknowledge the courtesy of the two principals, the teachers and the learners in the two schools to work with them for three weeks: one week for acclimatisation and two for the teaching.

\section{Declaration of Conflicting Interests}

The authors declared no potential conflicts of interest concerning the research, authorship, and publication of this article.

\section{Funding}

The authors received no financial support for the research and authorship of this article.

\section{References}

Ajaja, O.P. (2009). Teaching methods across disciplines. Ibadan: Bomn Prints.

Akanbi, A.A., \& Kolawole, C.B. (2014). Effects of guided-discovery and self-learning strategies on senior secondary school students' achievement in biology. Journal of Education and Leadership Development, 6(1), 19-42. https://www.cenresinjournals.com/wp-content/uploads/2020/02/Page-19-42-0097.pdf

Amukowa, W., \& Karue, N. (2013). Analysis of factors that lead to poor performance in Kenya certificate of secondary examination in Embu district in Kenya. International Journal of Social Sciences, 13(1), 92-108. https://tiioss.com/TIJOSS\%2013th\%20Volume/Amukowa.pdf

Ayyildiz, Y., \& Tarhan, L. (2012). The Effective Concepts on Students' Understanding of Chemical Reactions and Energy. Hacettepe University Journal of Education, 42, 72-83. https://doi.org/10.1037/h0025943

Baek, J., Yoo, Y., Lee, K., Jung, B., \& Baek, Y. (2017). Using an Instant Messenger to Learn a Foreign Language in a Peer-Tutoring Environment. Turkish Online Journal of Educational Technology-TOJET, 16(2), 145-152. Retrieved from: https://files.eric.ed.gov/fulltext/EJ1137819.pdf

Bussey, K., \& Bandura, A. (1999). Social cognitive theory of gender development and differentiation. Psychological Review, 106(4), 676-713. https://doi.org/10.1037/0033-295X.106.4.676

Charles, M., \& Bradley, K. (2009). Indulging our gendered selves? Sex segregation by field of study in 44 countries. American Journal of Sociology, 114, 924-976. https://doi.org/10.1086/595942

Choma, S.S.R., Alberts, M., \& Urdal, P. (2007). Effect of traditional beer consumption on the iron status of a rural South African population. South African Journal of Clinical Nutrition, 20, 62-68.

https://doi.org/10.1080/16070658.2007.11734125

Clark, R.E., Kirschner, A.P., \& Sweller, J. (2006). Why minimal guidance during instruction does not work: An analysis of the failure of constructivist, discovery, problem-based, experiential, and Inquiry-based teaching. Educational Psychologist, 41(2), 75-86. https://doi.org/10.1207/s15326985ep4102_1

Cohen, L., Manion, L., \& Morrison, K. (2007). Research methods in education (2nd ed.). Canada: Routledge. https://doi.org/10.4324/9780203029053

Department of Basic Education (2012). National Senior Certificate Examination, National Diagnostic Report. Republic of South Africa, Pretoria.

DfES (2002). Time for Standards - Reforming the school workforce. London: HMSO

Dhurumraj, T. (2013). Contributory factors to poor learner performance in Physical Sciences in KwaZulu-Natal Province with special reference to schools in the Pinetown District. Doctoral dissertation. University of KwaZulu-Natal. 
Garuma, A., \& Tesfaye, G. (2012). The effect of guided discovery on students' physics achievement. Journal of Physics Education, 6(4), 530-537. https://citeseerx.ist.psu.edu/viewdoc/download? $\underline{\text { doi }=10 \cdot 1 \cdot 1 \cdot 668.6710 \& \mathrm{rep}=\text { rep } 1 \& \text { type }=\text { pdf }}$

Khan, A., Egbue, O., Palkie, B., \& Madden, J. (2017). Active Learning: Engaging Students to Maximize Learning in an Online Course. The Electronic Journal of e-Learning, 15(2),107-115. Available at: http://rapidintellect.com/AEQweb/ed-5987.pdf

Kibirige, I., \& Tsamago, H. E. (2019). Grade 10 learners' science conceptual development using computer simulations. Eurasia Journal of Mathematics, Science and Technology Education, 15(7), 1-17. https://doi.org/10.29333/ejmste/106057

Kirschner, P., Sweller, J., \& Clark, R. (2006). Why minimal guidance during instruction does not work: an analysis of the failure of constructivist, discovery, problem-based, experimental and inquiry-based teaching. Educational Psychologist, 40, 75-86. https://doi.org/10.1207/s15326985ep4102_1

Loibl, K., \& Rummel, N. (2014). Knowing what you don't know makes failure productive. Learning and Instruction, 34, 74-85. https://doi.org/10.1016/j.learninstruc.2014.08.004

Magana, A. J., Vieira, C., \& Boutin, M. (2018). Characterizing engineering learners' preferences for active and passive learning methods. IEEE Transactions on Education, 61(1), 46-54.

https://doi.org/10.1109/TE.2017.2740203

Makarova, E., Aeschlimann, B., \& Herzog, W. (2019). The gender gap in STEM fields: The impact of the gender stereotype of math and science on secondary students' career aspirations. Frontiers in Education, 4, 1-60. https://doi.org/10.3389/feduc.2019.00060

Marina, I.S., Vladimir, M.P. \& Bojan, T.Š. (2012). Addressing students' misconceptions concerning chemical reactions and symbolic representations. Bulgarian Journal of Science Education, 21(6), 829-852.

Martin, A.J. (2015). Teaching academically at-risk students in middle school: The roles of explicit instruction and guided discovery learning. In Groundwater-Smith, S., \& Mockler, N. (Eds.), Big fish, little fish: Teaching and learning in the middle years. Cambridge: Cambridge University Press.

Mayer, R.E. (2004). Should there be a three-strike rule against pure discovery learning? The case for guided methods of instruction. American Psychologist, 59(1), 14-19. https://doi.org/10.1037/0003-066X.59.1.14

Mazzoni, E., \& Gaffuri, P. (2009). Monitoring Activity in e-Learning: a quantitative model based on web tracking and Social Network Analysis. In: Juan, A., Daradoumis, T., Xhafa, F., Caballe, S., \& Faulin. J. (Eds.), Monitoring and assessment in online collaborative environments: emergent computational technologies for E-learning Support (111-130). IGI Global. https://doi.org/10.4018/978-1-60566-786-7.ch007

McMillan, J., \& Schumacher, S. (2010). Research in Education. Evidence base Inquiry (7th ed.). International Edition Boston. Pearson Education Inc.

Michael, J. (2006). Where's the evidence that active learning works? Advance in Physiology Education, 30, 159-167. https://doi.org/10.1152/advan.00053.2006

Mji, A., \& Makgato, M. (2006). Factors associated with high school learners' poor performance: a spotlight on mathematics and physical science. South African Journal of Education, 26(2) 253-266.

https://www.ajol.info/index.php/saje/article/view/25068

Moreno, R. (2004). Decreasing cognitive load for novice students: effects of explanatory versus corrective feedback in discovery-based multimedia. Instructional Science, 32(1), 99-113.

https://doi.org/10.1023/B:TRUC.0000021811.66966.1d 
OECD (2006). Evolution of Student Interest in science and Technology Studies. Policy Report. Available at: https://www.oecd.org/science/inno/36645825.pdf

Owens, D.C., Sadler, T.D., Barlow, A.T., \& Smith-Walters, C. (2020). Student motivation from and resistance to active learning rooted in essential science practices. Research in Science Education, 50(1), 253-277. https://doi.org/10.1007/s11165-017-9688-1

Peterson, P.L. (1979) Direct instruction reconsidered. In: Peterson, P.L., \& Walberg, H.L. (Eds.), Research on Teaching: Concepts, Findings and Implications. Berkeley, CA: McCutchan.

Petrus, R.M. (2018). A Comparison of 'Teachers' and Students' Perceptions of the Factors Contributing to Poor Performance in Physical Sciences: A case of South Africa. Journal of Turkish Science Education, 15(4), 93-103. https://doi.org/10.12973/tused.10248a

Reinking, A., \& Martin, B. (2018). The gender gap in stem fields: Theories, movements, and ideas to engage girls in STEM. Journal of New Approaches in Educational Research, 7(2): 148-153. https://doi.org/10.7821/naer.2018.7.271

Roberts, D. (2019). Higher education lectures: From passive to active learning via imagery? Active Learning in Higher Education, 20(1), 63-77. https://doi.org/10.1177/1469787417731198

Scheyvens, R., Griffin, A.L., Jocoy, C.L., Liu, Y., \& Bradford, M. (2008). Experimenting with active learning in geography: dispelling the myths that perpetuate resistance. Journal of Geography in Higher Education, 32, 51-69. https://doi.org/10.1080/03098260701731496

Seidel, S.B., \& Tanner, K.D. (2013). "What if students revolt?" -considering student resistance: origins, options, and opportunities for investigation. CBE Life Science Education, 12, 586-595.

https://www.lifescied.org/doi/pdf/10.1187/cbe-13-09-0190

Shekhar, P., Demonbrun, M., Borrego, M., Finelli, C., Prince, M., Henderson, C. et al. (2015).

Development of an observation protocol to study undergraduate engineering student resistance to active learning. International Journal of Engineering Education, 31, 597-609. https://citeseerx.ist.psu.edu/viewdoc/download?doi=10.1.1.702.2980\&rep=rep1\&type=pdf

Shieh, C.J., \& Yu, L.A. (2016). Study on Information Technology Integrated Guided Discovery Instruction toward Students Learning Achievement and Learning Retention. Eurasia Journal of Mathematics, Science \& Technology Education, 12(4), 833-842. https://doi.org/10.12973/eurasia.2015.1554a

Talheimer, W. (2010). Cognitive Load Theory Coming Under Withering Attacks. Available at: http://www.willatworklearning.com/

Udo, M.E. (2010). Effect of guided-discovery, student centred demonstration and the expository instructional strategies on students' performance in chemistry. An International Multi-Disciplinary Journal, 4(4), 389-398. https://doi.org/10.4314/afrrev.v4i4.69237

Udo, M.E., \& Udo, N.J. (2007). Instructional methods and the performance of students with different reasoning abilities in chemistry. International Journal of Educational Development, 10(1), 52-61.

van der Berg, S., van Wyk, C., Burger, R., Kotzé, J., Piek, M., \& Rich, K. (2017). The Performance of Low Fee Independent Schools in South Africa - What Can Available Data Tell? Stellenbosch Economic Working Papers, 1. Stellenbosch. https://doi.org/10.2139/ssrn.2973229

Vosniadou, S., Ioannides, C., Dimitrakopoulou, A., \& Papademetriou, E. (2001). Designing learning environments to promote conceptual change in science. Learning and Instruction, 11, 381-419.

https://doi.org/10.1016/S0959-4752(00)00038-4 
Vygotsky, L.S. (1978). Internalization of higher psychological functions. Mind in society: The development of higher psychological processes (52-57). https://scholar.google.com/citations?user=L4S0dT0AAAAJ\&hl=en\&oi=sra

Yerizon, Putra, A.A., \& Subhan, M. (2018). Mathematics Learning Instructional Development based on Discovery Learning for Students with Intrapersonal and Interpersonal Intelligence (Preliminary Research Stage). International Electronic Journal of Mathematics Education, 13(3), 97-101.

https://doi.org/10.12973/iejme/2701

Zohar, A., \& Barzilai, S. (2013). A review of research on metacognition in science education: Current and future directions. Studies in Science education, 49(2), 121-169. https:// doi.org/10.1080/03057267.2013.847261

\author{
Published by OmniaScience (www.omniascience.com) \\ Journal of Technology and Science Education, 2021 (www.jotse.org)
}

\title{
(c) (i) (8)
}

Article's contents are provided on an Attribution-Non Commercial 4.0 Creative commons International License. Readers are allowed to copy, distribute and communicate article's contents, provided the author's and JOTSE journal's names are included. It must not be used for commercial purposes. To see the complete licence contents, please visit https://creativecommons.org/licenses/by-nc/4.0/. 